\title{
THE IMPROVEMENT CRITICAL THINKING ABILITY OF STUDENTS THROUGH RECIPROCAL LEARNING (RECIPROCAL TEACHING) AND JIGSAW MODELS IN BIOLOGICAL LESSON IN PARLAUNGAN ISLAMIC HIGH SCHOOL AND AL-MUSLIM HIGH SCHOOL.
}

\author{
Slamet $^{1)}$, Djoko Adi Walujo ${ }^{1)}$, Sugito ${ }^{1)}$ \\ 1) Program Studi Teknologi Pendidikan, Program Pascasarjana Universitas PGRI Adi Buana Surabaya \\ Jawa Timur \\ email: parlaungan_sma@yahoo.com
}

\begin{abstract}
Reciprocal teaching is one of learning model which is consist of four strategies: summarizing, questioning, claryfying the knowladge, and predicting. Another type of cooperative learning is jigsaw models. Jigsaw is a cooperative learing model which create some expert learning groups to stimulate critical thinking of the student abilities. Jigsaw is a learning model that triggers student to have active role in group learning. This study was to know the effect of Reciprocal Teaching with Jigsaw learning model on student critical learning ability is important to be exposure because its study shows that the 10th grade high school students had a low critical thinking abilities. As pre-test and post-test statistical data showed the influence of prior knowledge on learning result has significance points of 0,443 >0,05., so it can be conclude that the data is significant. Based on the data, there are influence between the prior knowledge to the crtitical thinking ability result. According to the statistical data, the influence of learning models on learning results has significance points of 0,060 >0,05., so it can be conclude that there are diffrence effect in critical thinking ability by using Reciprocal teaching vs Jigsaw models. Based on the data, the significance points are 0,126 >0,05., it indicates that the students learning results data is valid or significant and it can be conclude that there are some interaction between Reciprocal teaching with Jigsaw model learning method and aperception knowledge on the learning result of 10th grade student critical thinking ability at Islam Parlaungan High School Waru and Al-Muslim High School Waru.
\end{abstract}

Keyword: Reciprocal learning model, Jigsaw model, critical thinking ability, learning result

\section{INTRODUCTION}

Reciprocal teaching is one of the learning models that has four strategies namely summarizing, questioning, solving problem with claryfying or explaining the knowledge that has been obtained, and predicting the next question of the problem presented to students. From this strategy, it can be seen that this learning models requires a lot of students thinking abilities, especially thinking at a higher level, namely critical thinking. Critical thinking enables students to study all of the problems systematically, face up to millions of challange in an organized way, formulate innovative questions, and design original solutions (Johnson, 2007) and Reciprocal teaching is a learning model that meets the indicators that exist in students critical thinking abilities.

The cooporative learning model encourages the improvement of students abilities to solving problems encountered during learning, because the students can work together with the others and formulate alternative solutions to the problem material being discussed. One type of coorporative learning model is Jigsaw type, cooperative learning model Jigsaw type is learning that forms groups of experts that are expected to improve Jigsaw thinking ability as learning that encourages students to be active in group learning. (Andriliani, 2005)

Bioedukasi Vol. XVII. No. 2 October 2019

Received 19 August 2019| Received in revised form 16 September 2019| Accepted 30 September 2019| Published online 7 October 2019 
Currently, critical thinking skills are needed to enhance learning activities because all of the global information comes easily, this causes in addition to information that is good or bad will continue to flow without stopping and can affect the mental nature of the childern. The ability to think clearly and imaginatively, assess evidence, play logic, and look for alternatives to find a solution, gives chidern a clear route in the midst of the chaos of thought in the current era of technology and globalization. (Johnson, 2007). They must be able to distinguish between good and bad reasons and distinguish truth from lies. They must know how to think critically.

Research on the effect of the Reciprocal teaching vs Jigsaw model on students critical thinking skills can be said to be necessary because based on the preliminary studies conducted by researchers show that critical thinking skills of high school students in class $\mathrm{X}$ are include in the bad category. Reciprocal teaching and Jigsaw learning models are done in groups, this is done so that students can work together and exchange opinions in learning. Material suitable for learning in groups must have sub-material that is quite interesting, such as environmental pollution in the biology subject material in class $\mathrm{X}$ senior high school. Environmental pollution material is selected in this study, so students are more enthusiastic in learning and discussing because generally students will more interested in material which is related to the environment, besides that students critical skills can be developed through studies related to life everyday (Zohar 1994). Conducting research in this way is done because Reciprocal teaching requires students to read and summarize learning activities that will and have been carried out, so students is not only learn in groups but also in their individual abilities to be better through dialogue based on the text. Reciprocal learning activities must also be adapted to subject matter that is suitable for groups activities and requires critical thinking skills with not too long time. Based on the things that have been explained above, it is necessary to do research on the influence of reciprocal teaching models (reciprocal teaching) with Jigsaw model and preliminary knowledge on learning outcomes of critical thinking skills in the subject of environmental polution material in biology lesson class $\mathrm{X}$ in Parlaungan Islamic High School Waru and AlMuslim High School Waru.

The purpose of this research is to determine the differences in the effect of applying reciprocal teaching models (reciprocal teaching) and jigsaw models on the learning outcomes of critical thingking skills, and to know the difference between the influence of high and low initial knowlegde on learning outcomes of critical thinking skills and the interaction between learning models and initial knowledge of participants students in biology lesson in class $\mathrm{X}$ Parlaungan Islamic High School Waru and Al-Muslim High School Waru. In this study it is hoped that the result can be used determine differences in the effect of applying reciprocal teaching model (reciprocal teaching) and jigsaw models on the learning outcomes of critical thinking skills, the effect of students initial knowledge and their interactions on biology lesson in class X Parlaungan Islamic High School Waru and Al-Muslim High School Waru. Besides that, it can be used as an alternative learning model in improving students critical thinking skills and their use for other lesson that are allied with biology, that requires students critical thinking skills. 


\section{RESEARCH METHODS}

This research is an experimental research to resolve the effect of independent varibles on the variables conducted. The experimental design used was a quasi pre-test post-test non equivalent control group design (Kerlinger 1986; Tuckman 1999 in Sulistyaningrum 2011). The independent variables in this study are reciprocal learning models (reciprocal teaching) and jigsaw models. The moderator variable (secondary independent variable) in this research is the initial knowledge of students. Initial knowledge includes high initial knowlegde and low initial knowledge. The successful variable in this study was the learning outcomes of students critical skills. The research was conducted at Parlaungan Islamic High School Waru and Al-Muslim High School Waru which located in Waru district, Sidoarjo, East Java. The reason for choosing this school because the researcher is familiar with the situation and characteristics of the students at the school, besides the learning model that will be offered has never been given to students at the school. The sample in this research used purposive sampling.

\section{RESEARCH RESULT}

Based on the purpose of this study is determine the effect of the Reciprocal vs Jigsaw models and the ability to start student critical thinking skills, the data collection is done by means of pre-test and post-test. The questions were used as a research instrument around 8 which contained 5 indicators and 7 subindicators of critical thinking skills. The total score for all critical thinking skills used is 32. The questions given contained 5 indicators with 7 subindicators of critical thinking ability. When the researcher applying pre-test, it is about 60 minutes. As in the research, the researcher used 2 models in measuring students ability to think critically. The Reciprocal learning model and the other model is Jigsaw which has produced varying capacity increases in each students learning.

Based on the result of the research showed that $64 \%$ of students in the critical thinking skills have a category were early enough to get a percentage between $55 \% \leq \mathrm{C}<75 \%$ of students in the category were less than the percentage value between $40 \% \leq \mathrm{D} 55 \%$, $25 \%$ of students have a good initial critical thinking skills with a percentage of between $75 \% \leq \mathrm{B}<75 \%$, and $3.5 \%$ of students in the excellent category. The proportion of the level of categories of students critical thinking skills can be seen from the diagram below:

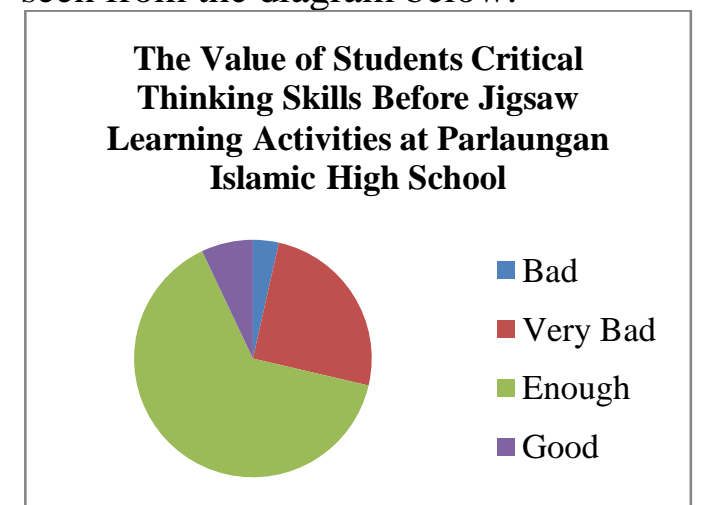

Figure 1: Diagram of percentage of Critical Thinking Ability of Students before Learning Jigsaw.

Based on the result of the research it can be seen that $68.75 \%$ of students are included in the category of initial critical thinking skills that are sufficient with the acquistion of a percentage of grades between $55 \% \leq \mathrm{C}<75 \%, 12.5 \%$ of students are in the less category with a percentage value of between $40 \% \leq \mathrm{D}$ $55 \%, 18.75 \%$ of students have a good inital critical thinking skills with a percentage of grades between $75 \% \leq \mathrm{B}<$ $75 \%$, and $0 \%$ of the students fall into the excellent category. A comparison of the percentage categories of students initial 
critical thinking ability levels can be seen through the diagram below:

\begin{tabular}{|} 
The Value of Students Critical \\
Thinking Skills Before Jigsaw \\
Learning Activities at Al- \\
Muslim high school \\
$\square$ Very Good \\
$\square$ Good \\
$\square$ Enough \\
$\square$ Bad
\end{tabular}

Figure 2: Diagram of percentage of Critical Thinking Ability of Students before Learning Jigsaw.

The comparasion of the percentage of students critical thinking ability level categories after learning can be seen through the diagram below:

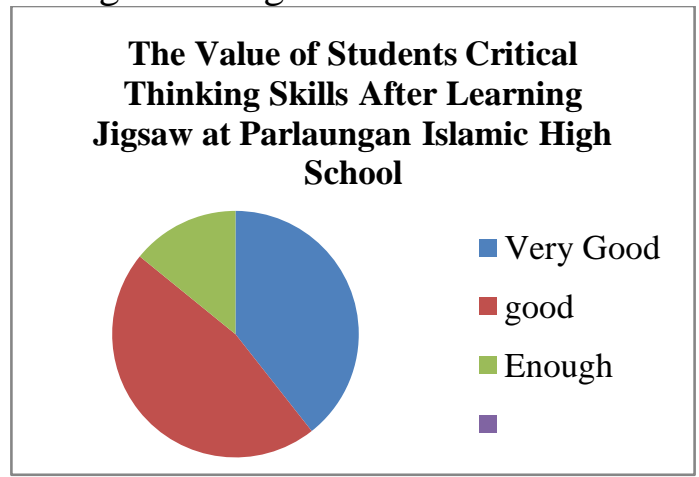

Figure 3: Diagram of Percentage of Critical Thinking Ability Students after Jigsaw Learning at Parlaungan Islamic High School

The comparasion of the percentage of students critical thinking ability level categories after learning can be seen through the diagram below:

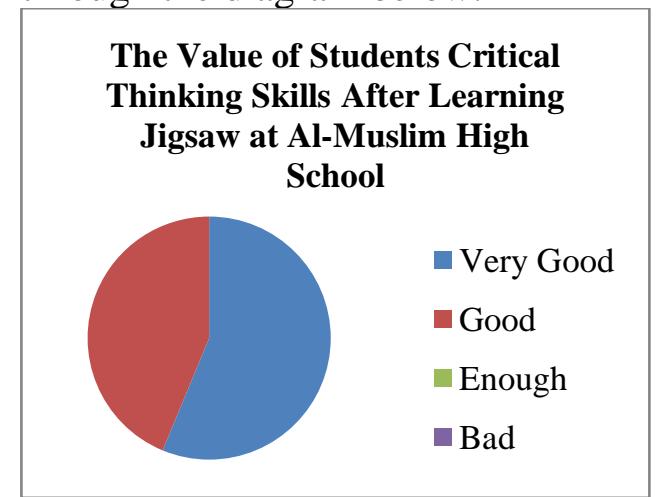

Figure 4: Diagram of Percentage of Critical Thinking Ability Students after Jigsaw Learning at al-Muslim High School.
Increased critical thinking skills with Jigsaw learning and reciprocal teaching can be seen from the magnitude of the gain index from the results of filling all the questions about students critical thinking skills can be seen from the table below:

Table 1: Gain Index of Critical Thinking

Ability Students with Jigsaw Model in

Parlaungan Islamic High School and

Reciprocal Teaching Model in Al-Muslim High School

\begin{tabular}{ccccc}
\hline & \multicolumn{2}{c}{$\begin{array}{c}\text { ISPA HIGH } \\
\text { SCHOOL }\end{array}$} & \multicolumn{2}{c}{$\begin{array}{c}\text { THE VALUE AL- } \\
\text { L MUSLIM HIGH } \\
\text { SCHOOL }\end{array}$} \\
\cline { 2 - 5 } & Pretest & Posttest & Pretest & Posttest \\
\hline$\sum$ & 1998 & 2412 & 1061 & 1456 \\
\hline $\bar{X}$ & 71.3571 & 86.142 & 66.3125 & 91 \\
\hline $\mathrm{N}$ & 28 & 28 & 16 & 16 \\
\hline
\end{tabular}

Gain index calculation is done to find out whether or not the influence of the Jigsaw model on students critical thinking skilss. In this research, the average gain index of 28 students in Parlaungan Islamic High School Waru was 0.4385 which was included in the sufficient category and in the use of the Reciprocal Teaching learning model, the average gain index of 16 students in AlMuslim High School Waru was 0.6898 which was included in the enough category.

Before starting the learning phase, students are given a pre-test that aims to determine the initial abilities of students, especially the critical thinking category of students. The average students score is 71.35 with the fair category. Based on the results of the research, it can be seen that $64 \%$ of students are included in the category of initial critical thinking skills sufficient with the acquisition of a percentage of grades between $55 \% \leq \mathrm{C}$ $<75 \%, 7 \%$ of students are in the less category with a percentage value between $40 \% \leq \mathrm{D}<55 \%, 25 \%$ of students had a good initial critical thinking skills with a percentage of

Bioedukasi Vol. XVII. No. 2 October 2019 
grades between $75 \% \leq \mathrm{B}<75 \%$, and $3.5 \%$ of students included in the excellent category. Based on the result of the research, it can be seen that $68.75 \%$ of students are included in the category of initial critical thinking skills that are sufficient with the acquisition of a percentage of grades between $55 \% \leq \mathrm{C}$ $75 \%, 12.5 \%$ of students are in the less category with a percentage value of between $40 \% \leq \mathrm{D}<55 \%, 18.75 \%$ of students have a good initial critial thinking skills with a percentage of grades between $75 \% \leq \mathrm{B} 75$, and $0 \%$ of students fall into excellent category.

In a general students is had never worked on problems related to critical thinking skills and assume that the questions given are difficult. Students are accustomed to the questions that lead directly to the answers that had been determined or more on memorization without further thinking stage. This proves that the questions that are usually given do not measure students thinking abilities. According to Ruggiero (1998) in Johnson (2007), defines critical thinking as all mental activities that help formulate a problem, make a decision or fulfill a desire to understand something. Thus it is clear that in the process of thinking a person must be able to connect knowledge with one anoher in order to solve a problems. So, if seen from the result of the pre-test obtained there is nothing doubt that students learning experiences only emphasize the mastery of concepts. So that when students are given a problem to be solved, students will experience difficulties. This is supported by the result of interviews with the teacher concerned, who stated that generally of the questions and learning targets are only limited to the mastery of concepts and is not direct how students can think more higher levels besides Reciprocal teaching and Jigsaw learning model are new to students and had never been used in the learning process. Cooporative learning model encountered during learning, because students can work together with the others to find and formulate alternative solution to the problems faced by the lesson or subject matter. One type of cooporative learning model is Jigsaw type, cooporative learning type Jigsaw is learning that forms a group of expert teams that are expected to stimulate critical thinking skills, because Jigsaw is a learning that triggers students to play an activate rolebin group learning (Andriliani, 2015). Based on the result of the research, it can be seen that $39.28 \%$ of students are included in the excellent category of critical thinking skills with the acquisition of a percentage of values between $90 \% \leq \mathrm{A} 100 \%, 46.42 \%$ of students are in the good category with a percentage of grades between $75 \% \leq \mathrm{C}$ $90 \%, 14.28 \%$ of students have sufficient critical thinking skills with a percentage of grades between $55 \% \leq \mathrm{C}<75 \%$, and none of the students fall into the bad category.

After learning with the Jigsaw model, the average post-test score of students increased to 86.14 where is was originally only 71.35 . So that there was an increase of \pm 15 numbers. Students who entered the category of critical thinking ability levels were very good at $39.28 \%, 46.42 \%$ of students were in the good category, and $14.28 \%$ of students were in the sufficient category, and the less to bad category was not found. This shows that learning with the Jigsaw model can improve the students critical thinking skills. Based on the table 4.5, it can be seen that $56.25 \%$ of students fall into the very good category of critical thinking levels with the acquisition of percentage grades between $90 \% \leq \mathrm{A}$ $100 \%, 43.75 \%$ of students are in the good category with percentage of grades between $75 \% \leq \mathrm{C} 90 \%$, and none of the 
students were included in the sufficient and bad categories. After learning with the Reciprocal teaching model, the average post-test score of students increased to 91, where was in the beginning it is only 66.31, resulting in an increase of 24 points. Students who are in the good critical thinking ability level are $43.75 \%$ and $56.25 \%$ of students are in the excellent category were enough, less or bad categories are not found. This shows that learning with the Reciprocal teaching model can improve students critical skills.

The learning phase is carried out using the Reciprocal teaching model according to Dyer (Palinscar, 1986), this is because in this model students are divided into small groups so that the discussion process can run more effectively, according to Gokhale's sugesstion (Sudaryanto, 2007) which states that learning through discussion in small groups are recommended as strategies that can improve cricitcal thinking skills. In the Reciprocal teaching model according to Dyer, there is a division of tasks between group members so that students can practice alternately into summaries, questioners who make clarifications and who make prediction besides the teacher in the learning process not acting as a model, but only acting as a facilitator who directs the discussion. Learning with the Reciprocal teaching model allows students to have a long discussion and in the discussion process, there is a lot of exchange of information from students who have a good knowlegde to students who have less knowledge about environmental pollution. Learning with the Reciprocal teaching model makes students help each other and find their knowledge by collaborating with friends and building their own knowledge using to helping a friends and reading resources. Improved students sbility to think critically is obtained by independent learning (without always depending on the teacher). The teacher only acts as a facilitator and helps students if the group is experiencing difficulties. When the learning takes place, the teacher only guides students to find the expected answers and directs how to make a good concepts maps, stimulate students to make a questions from the data presented, and monitors students in the discussion process to determine a prediction of a problem that arises and becomes moderator during the class discussion or presentation process. In addition, the teacher guides students to draw conclusions from the material that has been given. This is in line with the opinion of Cadre (1995) which states that Reciprocal teaching can help students to learn in the absence or absence of teachers. Based on figure 4.5, the majority of students have sufficient gain index of $60.71 \%$ where $25 \%$ of students have a high gain index, and $14.28 \%$ of the students have a low gain index. Based on the research, it can be seen the comparison of the average percentage of students preliminary and final (post-test) critical thinking skills. The average percentage of pre-test was $71.35 \%$ and the average percentage of post-test was $86.14 \%$. from the average we can know that the average percentage of students critical thinking skills increased by $14.78 \%$.

Based on the research result, the majority of students have a sufficient gain index $56.25 \%$ and $43.75 \%$ of students have a high gain index. Based on the result, it can be seen the comparison of the average percentage of the ability of critical thinking beginning (pre-test) and at the final (post-test) students. The average percentage of pretest was $66.3125 \%$ and the average percentage of post-test was $91 \%$. From the average we can know that the 
average percentage of students critical thinking skills increased by $25 \%$. Based on the data on the research, the average gain index of critical thinking skills of class $X$, the students of Parlaungan Islamic High School Waru is categorized sufficient, that is equal 0.4385 . the number shows that the Jigsaw learning model is a good learning model to improve students critical thinking skills. The result of the research show that $14.28 \%$ of students have a gain index between $0.00-0.29$ which is categorized as low, $60.71 \%$ of students have a gain index between $0.3-0.69$ are categorized as sufficient, and $25 \%$ of students have a gain index between 0.7 and 1.00 which is categorized as a higher. The percentage of the student outcome categories shows that Jigsaw is learning model that has an effect on increasing students critical thinking skills. Based on the data, the average gain index of critical thinking skills of class X students of Al-Muslim High School was categorized as sufficient, that is 0.663 . the number shows that the Reciprocal teaching learning model that is good enough to improve students critical thinking skills. In the result of, it can be seen that by $0 \%$ students have a gain index between 0,00 -0.29 which is categorized low, $56.25 \%$ students have a gain index between $0.3-$ 0.69 which is considered sufficient, and $43.75 \%$ students have a gain index between $0.7-1.00$ which is categorized high. The percentage of student outcome categories shows that reciprocal teaching is a learning model that has an effect on increasing students critical skills.

In generally, the students was feel confused or do not know what to say when they have to interact with the other people. But after the learning is done, all of the student involved in discussions and information exchange occurs and it can train of the students to communicate with others, namely in one group and presentations other that that. Learning with the Reciprocal teaching model allows students to discuss for a long time and in that discuss process, there is a lot of information from the other student who have a good knowledge to students who have a less knowledge about environmental pollution. learning with the Reciprocal teaching model makes students to help each other and find out their knowledge by collaborating with friends and build their own knowledge with using the help of friends and reading some resource. Improved students ability in critical thinking is obtained by learning to stand alone (without depending on the teacher). When learning activities take place, the teacher only acts as a facilitator and students are required to be active in the group, this is intended so that the exchange of information between students goes well. Student activities is undertaken in Reciprocal teaching learning also show some independent learning activities according to Diedrich (Wawa, 2004), as explained in chapter II, visual namely activities, namely reading or paying attention to worksheets and source book; oral activities, namely the ability to express, formulate or ask questions; listening activities, namely listening to the description or discussion; Writing activities, namely writing result of the discussion; Drawing activities and Emotional activities, which are interested or having fun. The result obtained from research that show Reciprocal teaching learning model is effective to improve the ability of critical thinking which supports the opinion (Wawa, 2004) that reciprocal teaching is appropriate to produce independent students, that is able to motivate themselves to improve learning and be able to overcome the problems faced. Increased motivation in overcoming these problems between pre-test and 
post-test that is large enough, so that reciprocal teaching is categorized as a learning model that can improve students critical thinking skills. The high of the student interest is in learning occurs because the reciprocal teaching learning model is a new learning model or has never been done before in biology lesson or subject.

\section{CONCLUSION}

Based on the result of the research, it can be concluded that there are differences in the influence of a high and low initial knowledge on learning outcomes of critcal thinking skills in the subject or lesson of environmental pollution material in biology class $\mathrm{X}$ at the Parlaungan Islamic High School Waru and Al-Muslim High School Waru with a significant value of $0.443>0.05$; there is a difference in the influence of the application of the reciprocal teaching models (Reciprocal teaching) and Jigsaw models on the learning outcomes of critical thinking skills in the subject or lesson matter of environmental pollution in the biology lesson class $\mathrm{X}$ at Parlaungan Islamic High School Waru and Al-Muslim High School Waru with a significant value of $0.060>0.05$; and there is an interaction between the application of the Jigsaw vs reciprocal teaching learning model and initial knowledge of the learning outcomes of critical thinking skills in the subject matter of environmental pollution in biology class $\mathrm{X}$ subject of Parlaungan Islamic High School Waru and AlMuslim High School Waru with a significance value of $0.126>0.05$.

\section{REFERENCE}

Afgani, D. 2005. Hubungan antara Persepsi Siswa terhadap Strategi Pembelajaran 'Logbook' dengan Hasil Belajar pada Sub Kkonsep
Organ Tumbuhan. Skripsi pada FPMIPA UPI Bandung: tidak diterbitkan.

Almukarrom, M. Ali, Evi A.2016. Penerapan Model Pembelajaran Kooperatif Jigsaw terhadap Peningkatan Kemampuan Bderfikir Kritis pada Konsep Pencemaran Lingkungan di SMA Negeri 12 Banda Aceh. Pascasarjana Univ Syah Kuala Aceh : Tidak diterbitkan.

Amalia, D.R. 2006. Pengaruh Pembelajaran Matematika Dengan MenggunakanModel Reciprocal Teaching Terhadap Kemampuan Berpikir kreatif siswaSMP. Skripsi pada FPMIPA UPI Bandung: tidak diterbitkan.

Anwar, L.2006. Penerapan Pendekatan Reciprocal Teaching Dalam Pembelajaran Matematika Dengan Menggunakan Media Komputer Untuk Meningkatkan Kemampuan Pemecahan Masalah. Skripsi pada FPMIPA UPI Bandung: tidak diterbitkan.

Arikunto, S. 2002. Dasar-Dasar Evaluasi Pendidikan. Jakarta: Bumi Aksara.

Cadre.1995. Reciprocal Teaching: A Reading Strategy. Dalam languange Arts cadre 95 [Online]., 2 halaman. Tersedia: http://www.sdcoe.k12.ca.us/score/ promising/tips/rec.html [12 Maret 2008].

Bioedukasi Vol. XVII. No. 2 October 2019 
Davis, B.G.1996. Collaborative Learning. Dalam Tools for Teaching Online], 5 halaman. Tersedia: http://teaching.berkeley. edu/bgd/collaborative.html [11 Maret 2008].

Dahar, Ratna W. 1996. Teori-teori Belajar. Jakarta: Erlangga.

Ennis, Robert H. 2000. An Outline of Goals for a Critical Thinking Curriculum and Its Assessment. [OnLine]. 5 halaman Tersedia: http://www.criticalthinking.net/in deks.html (7 Februari 2008).

Gejor. 2006. Pencemaran Lingkungan. [Teknik Lingkungan ITB [Online] 7 halaman.Tersedia: http://astac ala.org/lingkungan.html (26 Juni 2006).

Hadisusanto, Suwarno. 2006. Biologi. Klaten : Intan Pariwara.

Heni, F.S. (2003). Pengaruh Reciprocal Teaching Terhadap Peningkatan Kemampuan Berkomunikasi dan Hasil Belajar Siswa Pada Konsep Alat Indera. Skripsi pada FPMIPA UPI Bandung: tidak diterbitkan.

Johnson. 2007. Contextual teaching and learning. Bandung: MLL.

Meltzer. 2003. The Relationship Between Mathematic Preparation and Conceptual Gain In Physic a Possible Hidden Variable in Diagnostic Pretest Scores. [On Line]. Tersedia: http://jps.alp. org./ajp. (3 Maret 2008).
Mulyadiana, T.S. 2000. Kemampuan Komunikasi Siswa Madrasah Aliyah Melalui Pembelajaran Kooperatif Pada Konsep Sistem Reproduksi Manusia. Tesis PPS: tidak diterbitkan.

Palincsar. 1986. Reciprocal Teaching. Dalam North Central Regional Educational Laboratory [Online], 2 halaman. Tersedia: http://www.ncrel.org/sdrs/areas/is sues/students/atrisk/at6lk38. 12Maret2008].

Rustaman, N.Y. 2003.Strategi Belajar Mengajar Biologi. Bandung: IMSTEP JICA.

. 2005. Strategi Belajar

Mengajar Biologi.Bandung:UM Press.

Ruseffendi. (1998). Statistika Dasar untuk Penelitian Pendidikan. Bandung : IKIP Bandung Press.

Rustini, J.2005. Kemampuan Berpikir Kritis Siswa Melalui Pembelajaran Kooperatif Think-Pair-Share dalam Kegiatan Praktikum Materi Pencemaran Air. Skripsi pada FPMIPA UPI Bandung: tidak diterbitkan.

Roslina, Haryanto, Aulia S. 2017. Analisis Penerapan Model Pembelajaran Kooperatif Tipe Jigsaw dan Pengaruhnya Terhadap Kemampuan Berfikir Kritis Siswa pada Materi Ikatan Kimia di kelas X SMAN 1 Muaro Jambi. Universitas Jambi : tidak diterbitkan. 
Sudjana. 2002. Metoda Statistika.

Bandung: Tarsito.

Sudaryanto. 2007. Kajian Kritis tentang Permasalahan Sekitar

Pembelajaran Kemampuan

Berpikir Kritis. [Online]. 7

halaman tersedia:

http:www.FKUI.ac.id/kritis.html

[29 November 2007]

Wawa, U. 2004. Pengaruh Penerapan

Model Reciprocal Teaching

Melalui Pembelajaran Kooperatif

Terhadap hasil Belajar Fisika.

Skripsi pada FPMIPA UPI

Bandung: tidak diterbitkan.

Zohar. 1994. The Effect of the Biology

Critical Thinking Project on the

Development of Critical Thinking [Online]. 4 halaman. Tersedia: Journal of Research in Science Teaching. 